Chuluunbaatar B., Iklasova A.

Cross-cultural comparison of the Republic of Kazakhstan and Mongolia

Чулуунбаатар Б., Икласова А.

Қазақстан және Монғолия: кросс-мәдени талдау

Чулуунбаатар Б., Икласова А.

Казахстан и Монголия: кросс-культурный анализ
This article provides a cross-cultural analysis of historical peculiarities of Kazakhstan and Mongolia, cultural and social lives of peoples living there. The article was written mostly as a comparison of spiritual and material cultures, common features and peculiarities of these two different nations.

Key words: Kazakhstan, Mongolia, cross-cultural comparison.

Берілген мақалада авторлар Қазақстан және көршілес жатқан Монғол мемлекетінің мәдени, тарихи және әлеуметтік өмірін кросс-мәдени тұрғылан салыстырады. Мақалада, негізінен, қазақ, және монғол халықтарының рухани және заттық мәдениетіндегі ұқсастықтар мен айырмашылықтар тілге тиек болған.

Түйін сөздер: Қазақстан, Монғолия, кросс-мәдени талдау.

В данной статье авторы дают кросс-культурный анализ историческим особенностям Казахстана и Монголии, отличительным чертам культурной и общественной жизни народов, населяющих эти страны. В статье в основном сравниваются и сопоставляются Ауховная и материальная культуры, их общие черты и особенности.

Ключевые слова: Казахстан, Монголия, кросс-культурный анализ. 


\section{CROSS-CULTURAL COMPARISON OF THE REPUBLIC OF KAZAKHSTAN AND MONGOLIA}

Short report. Kazakhstan is a sovereign country with a total land area of approximately 2,724,900 square kilometers. In August, 2015 the population of Kazakhstan is overpassed 17000000 people. Ethnic Kazakhs, a mix of Turkic and Mongolian nomadic tribes migrated to the region by the 13th century became the one nation. Modern Kazakhstan borders five different countries: China (on the East); Russia (on the North), Turkmenistan, Uzbekistan, and Kyrgyzstan (on the South) [1].

Mongolia is a landlocked country wedged between two regional superpower countries- Russian Federation and China. The population of Mongolia is nearly 3,042,511 people with the density of less than 2 people per square $\mathrm{km}$. Total land area is approximately $1,565,000$ square kilometers. As it is known from the historical sources, in 1206 Great Leader Genghis Khan for the first time tied up all Mongolian tribes together and established a unified state. The Steppe Empire and nomadic culture of ancient Mongolians took a unique place in the World history [2].

According to foregoing information we can find some similarities: both two countries are landlocked and their territorial landscape is steppe. We compared some historical parts and population, which is have an obvious difference: Kazakhstan's population 5 times more than Mongolian.

Personal appearance of Kazakhs and Mongolians is very similar; it confirms the misunderstanding of the local people when they understand that I'm foreigner.

The climate of Kazakhstan and Mongolia is extremely variable: very hot summers, with temperatures over $38^{\circ} \mathrm{C}$, cold winters, when the temperature can reach even $-30^{\circ} \mathrm{C}$, with strong winds, making the temperature feel like $-46^{\circ} \mathrm{C}$ or $-51^{\circ} \mathrm{C}$. Astana and Ulan-Bator are two capital cities of these countries and the coldest places in each region; by the way Ulan-Bator is the coldest capital city in the world.

Symbols. Historically Kazakhs have a nomadic roots, thus a lot of their cultural symbols reflect the nomadic background. For example, horse is probably the most central part of Kazakh culture. Kazakhs like this animal, riding, using them in farming needs and eating as a delicious meal during the some kind of celebrations. Mongolians respect the horses too, especially as a product of their nomadic lives - the yurt or Mongolian Ger which is the Central 
Asian dwelling and resembling tepee, it was famous because if its transportability and utilitarity on the severe conditions of Great Steppe. These small white houses are still becoming found in some parts of Kazakhstan, but here they are mostly used during the celebrations, murals and tourist crafts. In Mongolian small villages people still use this type of dwellings. Another important part of Kazakh symbolism is Muslim symbolic. Kazakhs are historically Muslims and even after seventy years of Soviet Regime, they still use Islamic symbols in their everyday life. Traditional Muslim crescent with the small star, small Muslim caps and some traditionally Muslim robes can be widely seen in the villages.

Kazakhs are also very proud of their mountains, rare animals such as snow leopards, eagles, and falcons (a large eagle appears on the Kazakh flag under a rising sun), and their national instrument Dombra, a two-stringed instrument with a thin neck and potbelly base, resembling a guitar. Mongolians are proud of the beauty of their nature and very respectful for horses, wolfs, Khan Garuda (fairy bird, which is symbol of Ulan-Bator). Mongolians also have Morin Khur - a two-stringed instrument which is sometimes can be named as horse-head fiddle.

History. Historically the territory of Kazakhstan had been inhabited by nomadic tribes. It changed in the 13th century, when Genghis Khan occupied the country as part of the Great Mongolian Empire. But because of internal struggles among the conquerors, the power eventually reverted to the nomads. By the 16th century, the Kazakh emerged as a distinct group, divided into three jüz (ancestor branches occupying specific territories). The Russians began gobble up the Kazakh steppe in the 18th century and by the middle of the 19th century, they nominally ruled all the Kazakh territories as part of the Russian Empire. After Russian Revolution of 1917 and subsequent civil war, the territory of modern Kazakhstan was changed for several times. Finally in 1936 it bacame the Kazakh Soviet Socialist Republic, considered an integral part of the Soviet Union.

At this time during the collapse of the Qing dynasty in 1911, Mongols established the Temporary Government of Khalkha. This was before the abdication of the last Qing Emperor and the establishment of the Republic of China. On December 29, 1911 Mongolia declared independence from the Qing dynasty; the National Revolution of 1911 finished the over 200 years of Qing occupation, but only after Revolution of 1921 Mongolians became independent from any kind of
Chinese dictature. After that country came under the control of the Soviet Union, which had aided its independence from China. In 1924 the Mongolian People's Republic was declared as a Soviet satellite state. After the anti-Communist revolutions of 1989 , in early 1990 Mongolia conducted its own peaceful democratic revolution. This led to a multi-party system, a new constitution of 1992, and shifted to a market economy.

From this information we can see that both countries have almost the same experience: - the $13^{\text {th }}$ century Mongolia conquered Kazakh's steppe; - we all had the Soviet Union's influence. But in Kazakhstan this influence is much more deeper.

Major Industries. Kazakhstan is a land rich for natural resources, with recent oil deposits making it to become one of the world leaders in potential oil reserves. In spite of oil \& gas Kazakh land is also rich for such mineral resources as oil, coal, ore, lead, zinc, gold, silver, metals and construction material. Kazakhstan produces about 40 percent of the world's chrome ore $\left(2^{\text {nd }}\right.$ place after South Africa). Besides the major fossil fuels and important minerals extraction, which are supported by foreign and governmental investment. In 1998 the industrial growth rate reached the point of 2.1 percent and became frustrating to a country and people with such a rich land, but such a poor infrastructure and rate of capital investment [3].

Economic activity in Mongolia has traditionally been based on herding and agriculture, however development of extensive mineral deposits of copper, coal, molybdenum, tin, tungsten, and gold gave a rise of industrial production [4]. Besides mining (21.8\% of GDP) and agriculture (16\% of GDP), another dominant industries composing GDP are wholesale, retail trade and service, transportation and storage, and other real estate activities. The underground economy gets almost $30 \%$ of the total amount of the official economy. In 2006, 68.4\% of Mongolia's export falls to the PRC, and the PRC supplied 29.8\% of Mongolia's imports [5].

Here is common to them: abundant natural resources. But the most important thing is the similarity of their usage.

Food. In Kazakh and Mongolian cultures food is becoming a part of the national heritage, the way of respecting and celebrating. Both nations are like to eat meat and very hospital.

During the food ingestion there are have to be done couple rules: there have to be more than enough food to eat and the meat of different types.

The Kazakhs are very respectful to their guests. Certain traditional Kazakh food are usually served 
only on special occasions such as parties, holidays, weddings, and funerals. The most notable of these is beshbarmak, traditionally made of horse meat. It is essentially boiled meat served with noodles and covered by a meat broth called soup. The host, usually a man, takes the various pieces of meat and gives them to the guests in order to show his respect. Each piece of the horse (or goat, sheep or cow, never chicken or pig) symbolizes a different attribute such as wisdom, youth or strength. Beshbarmak is always serves in large plate and usually piping hot.

Sometimes beshbarmak can be made of lamb, the head of the sheep must be boiled, fully intact and served to the most respected guest. That guest can take a bit of meat for himself or herself and give the other parts of the head to other people at the table.

Another national food presented in all kinds of celebrations is baursak, a deep-fried bread with nothing in the middle and usually have a triangle or a circle forms. It serves with the meal, not as dessert, and it is usually strewn all over the traditional Kazakh table, which is called dastrakan (the word refers more to a table full of traditional food than to an actual table). Baursak is strewn all over the table so there is no any part of the table is showing. Kazakhs like to have every inch of service area covered with food, sometimes with more food than will fit on the table, as a way of the respect and prosperity. In Mongolia we have a type of similar food named boortsog, it's little bit crusty a little oiled bread.

A fermented horse's milk in Kazakh calls kymys and it is mostly drunk at ceremonial occasions. This traditional milk dates back to the nomadic days, and many people in Central Asia believe that its intoxicating beverage can be used in therapeutic. In Mongolia we call it airag and it has s small alcoholic percentage.

In both countries vodka is consumed at almost ceremonies. It is usually consumed in large quantities, and can be homemade or bought from the shops or liquor markets (although usually only Russians make it at home). During the drinking of vodka traditionally thee is must be said a toast. Vodka bands together Kazakh and other cultures, it is central to all important meals and celebrations. But nowadays young generation in Kazakhstan refuse the drinking of alcohol, it's very ravishing.

Government. In the beginning of establishing of the sovereign country, american legal and constitutional experts helped the Kazakhstani government to write their first Constitution and form their government in 1995. The political regime is a Presidential Republic. President having the power to dissolve the parliament if his prime minister is rejected twice or if there is a vote of no confidence. The president also is the only person who can suggest constitutional amendments and make political appointments. There are some forms of checks and balances provided by a bicameral legislature called the Kenges. The Majlis, or lower house, has sixtyseven Deputies and the upper house, the Senate, has forty-seven Senators, but their legislative functions are severely limited, they have no power to initiate legislation themselves. The legal system is based on the civil law system. There is a Supreme Court of forty-four members and a Constitutional Court of seven members. Although the main control power has a President. There are fourteen provinces or states in Kazakhstan, called oblast, with mayors and certain rights.

Mongolia is a parliamentary republic. The President is elected. People also elect the Deputies in the national assembly, the State Great Khural, which chooses the prime minister, who nominates the Cabinet together with the President. The Khural confirms the Ministers. Mongolian Constitution guarantee them some freedom, including full freedom of expression and religion. Mongolia has a number of political parties; the largest are the Mongolian People's Party and the Democratic Party.

Mongolia uses a unicameral parliamentary system where the President has a nominative role and the Government are choosing by the legislature exercises executive power. The legislative part, the State Great Khural, has one Chamber with 76 seats and is chaired by the Speaker of the House. Members are electing every four years by general elections.

We are democratic countries, but we using different type of political regime. In Kazakhstan the most powerful person is a President, but in Mongolia President takes only nominative role in political system.

\section{Conclusion}

According to the foregoing we can conclude that both countries have similar and totally different sides. They all have nomadic history and until now they still retain the nomadic culture. In sphere of religion they have absolutely different types of belief. Kazakhstan and Mongolia don't have common border lines, but they very close to each other in geographical position. I hope our countries can have a bright future and participatory development and what is the most this two countries have to respect and protect their unique culture. 


\section{References}

1 “2015 Human Development Report” (PDF). United Nations Development Programme. 2015.

2 “Mongolia". Encyclopædia Britannica Online. July 11, 1921. Retrieved 2013-06-28.

3 "Перепись населения Республики Казахстан 2009 года. Краткие итоги. (Census for the Republic of Kazakhstan 2009. Short Summary)» (in Russian). Republic of Kazakhstan Statistical Agency. Archived from the original (PDF) on 12 December 2010. Retrieved 10 December 2010.

4 "Background Note: Mongolia". Bureau of East Asian and Pacific Affairs.

5 Morris Rossabi; Vladimir Socor (May 5, 2005). "Beijing's growing politico-economic leverage over Ulaanbaatar". Jamestown Foundation. Retrieved 2013-06-28.

6 Abazov, Rafis. The Formation of Post-Soviet International Politics in Kazakhstan, Kyrgyzstan, and Uzbekistan, 1999.

7 Abraham, Kurt S. "A World of Oil-Kazakhstan, an Oasis in FSU Bureaucratic Quagmire; International Deals." World Oil, 220 (11): 29, 1999.

8 Bhavna, Dave. "Politics of Language Revival: National Identity and State Building in Kazakhstan." Ph.D. Dissertation, Syracuse University, 1996.

9 “Хүрээлэнгийн эрдэм шинжилгээний ажлын ололт амжилт”. Institute of Mongolian Archaeology. June 24, 2013. Retrieved 2013-06-28.

10 “2015 Human Development Report” (PDF). United Nations Development Programme. 2015.

11 “Mongolia”. Encyclopædia Britannica Online. July 11, 1921. Retrieved 2013-06-28.

12 "Perepis' naselenija Respubliki Kazahstan 2009 goda. Kratkie itogi. (Census for the Republic of Kazakhstan 2009. Short Summary)" (in Russian). Republic of Kazakhstan Statistical Agency. Archived from the original (PDF) on 12 December 2010. Retrieved 10 December 2010.

13 "Background Note: Mongolia". Bureau of East Asian and Pacific Affairs.

14 Morris Rossabi; Vladimir Socor (May 5, 2005). "Beijing's growing politico-economic leverage over Ulaanbaatar". Jamestown Foundation. Retrieved 2013-06-28.

15 Abazov, Rafis. The Formation of Post-Soviet International Politics in Kazakhstan, Kyrgyzstan, and Uzbekistan, 1999.

16 Abraham, Kurt S. "A World of Oil-Kazakhstan, an Oasis in FSU Bureaucratic Quagmire; International Deals." World Oil, 220 (11): 29, 1999.

17 Bhavna, Dave. "Politics of Language Revival: National Identity and State Building in Kazakhstan." Ph.D. Dissertation, Syracuse University, 1996.

18 "HYrjejeljengijn jerdjem shinzhilgjejenij azhlyn ololt amzhilt". Institute of Mongolian Archaeology. June 24, 2013. Retrieved 2013-06-28. 